\title{
OBITUAR Y
}

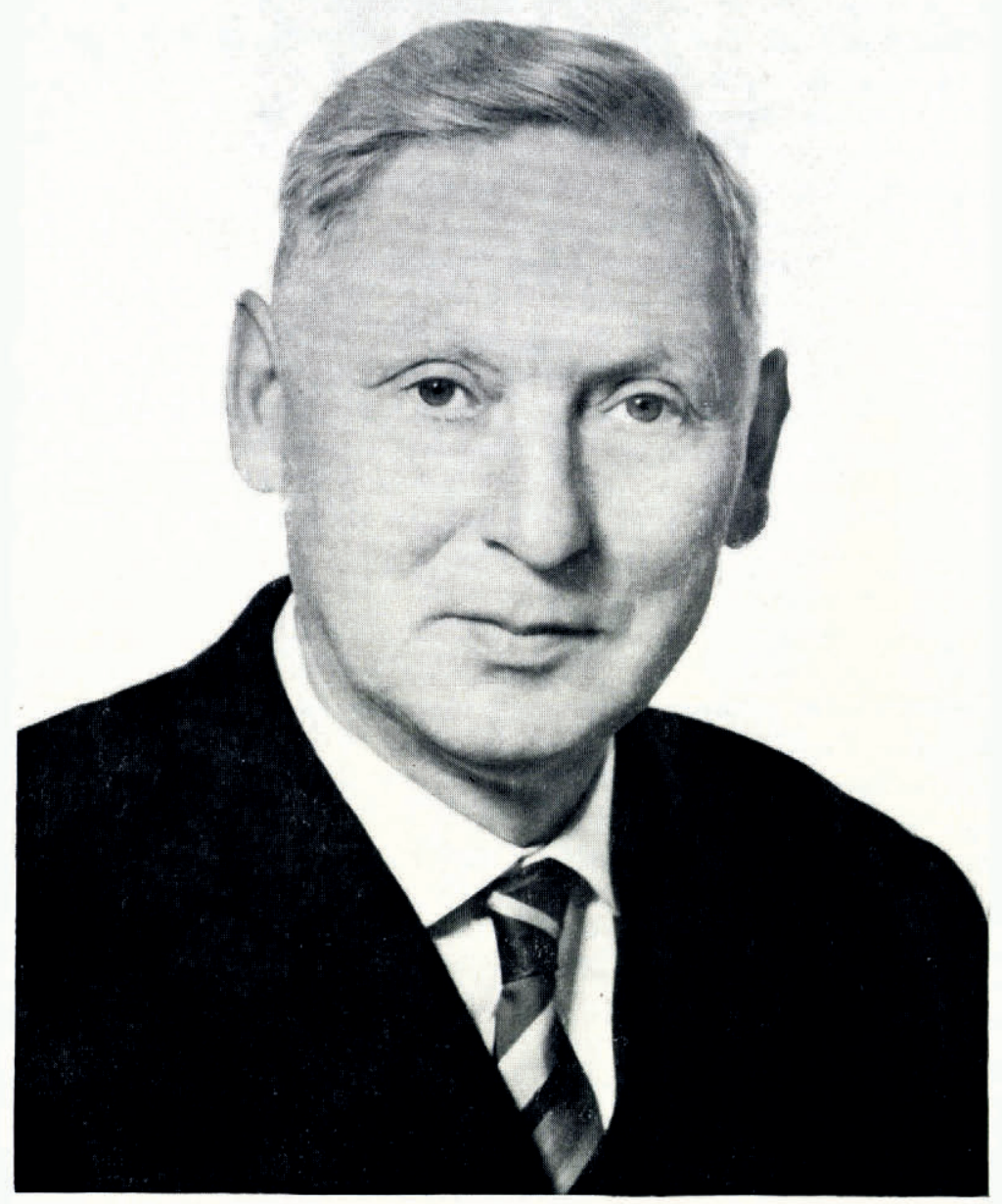

ANDRÉ RENAUD-I904-I964

ON 8 June i964, André Renaud died suddenly after a heart attack. The son of a schoolteacher, he was born on I4 August 1904 in Bremblens sur Morges, Switzerland. After a successful period at the Gymnasium he studied science at the University of Lausanne, where he gained the Licence ès Sciences. His special interest was botany, and he attended the lectures of Professor Chaudet at the University of Geneva.

After his happy marriage to Mademoiselle Madeleine Chessex in 1929, he was appointed teacher of science at Yverdon. In the same year he went on his first big expedition to the Arctic. As a young and enthusiastic associate of Professor Mercanton he accompanied him on board Charcot's Pourquoi Pas? to Greenland and Jan Mayen, an experience which was to have important effects. From 1945 he taught chemistry and physics in the Kantonschule of the Vaud, and in 196I he was appointed teacher of physics at the Gymnasium in Lausanne, where he worked devotedly, and enjoyed general affection, until his death.

From 1933, Renaud was a member of the Gletscherkommission of the Schweizerischer 
Naturforschenden Gesellschaft, in which he took part not only as a scientist, but also as a man and a friend; his death has meant a sad loss to this body, to which he had brought an unusual amount of selfless work, of stimulation and of encouragement. In addition to the post of Treasurer and Secretary, he was willing, after the retirement of Professor Mercanton, to undertake the time-consuming work, begun by F.-A. Forel in I88o, of continuing the yearly glacier observations of the Swiss Alps, a work without parallel anywhere in the world. He did this at the behest of the Commission, as well as supervising carefully and critically the publication of the observations in Die Alpen, the journal of the Schweizer Alpenclub.

For fifteen years he undertook this work for the Gletscherkommission, not only as a labour of love, but also for the purpose of improving the methods of the observations. In this, his personal contact with the observers was important. In 1936 he directed seismic soundings on the Unteraargletscher with the new seismographs of Professor Kreis, and over the years a map of the bottom topography of this glacier was compiled, with Renaud placing himself at the disposal of Dr. W. Jost during many summer holidays for this important task of the Gletscherkommission. After a long interval, caused by the second World War, this work only came to its successful conclusion in 1948 . With equal activity Renaud had continued his glaciological researches for the Gletscherkommission on the cold ice mantle of the Jungfraujoch.

In the last period of his life, the three years of preparation for Expédition Glaciologique Internationale au Groenland-E.G.I.G. (1957-6o) - and its projected sequel laid claim to much of his energy. During this international collaboration in Greenland he took part in three expeditions on the ice sheet, in which he joined forces with Professor Oeschger (Bern) and Professor Schumacher (Zürich) principally in the estimation of the age of the ice by a new chemical-physical method.

As the list of Renaud's scientific publications shows, he devoted most of his time to these glaciological problems. After studies of the glacier mills on the Gornergletscher, which he regarded as his favourite glacier and which he knew better than anyone else, he tried to delve more deeply into the secrets of the glacier crystal from the chemical-physical side. Unfortunately it was not possible for him to see in printed form the volume of Meddelelser om Gronland which contained the fruits of his research concerned with E.G.I.G. in I959.

In March 1964 he visited Thule in North Greenland, with Profesor Oeschger, on the invitation of American glaciologists, in order to investigate the variation of the tritium content of the ice there by the method developed in the Physikalische Institut der Universität Bern. This was a last well-deserved satisfaction and honour for the untiring research worker.

He did not know that the financing of a greatly desired important glaciological project, which he wanted to carry out in the following year, had been approved by the Fonds National Suisse de la Recherche Scientifique, and that funds were on their way to him.

In the Army Renaud was Festungskommandant with the rank of Oberstleutnant. His colleagues and friends grieve for him as a fine man of exceptional amiability and willingness to help. Our deepest sympathy goes to his family and especially to his widow who stood faithfully by his side in pleasure and pain, and who accompanied him so often to the glaciers. If the life and work of Renaud arouse our admiration, our thanks must also go to his wife for the great moral support she gave him.

R. Haefeli 